\title{
The Literature of Exile after 1939: A Bridge between Catalan Collective Memory and Identity
}

\author{
Montserrat Corretger (Department of Catalan Studies, Universitat Rovira i Virgili) ${ }^{*}$ \\ montserrat.corretger@urv.catｈttp://orcid.org/0000-0002-8700-6952
}

\begin{abstract}
The present article reflects on and emphasises the importance of the still-unrecognised work by Catalan writers who bore witness to the exile of 1939 and the preceding historical period of the Second Spanish Republic (1931-1939) and the Civil War (1936-1939). The article explores how these exiled writers and their literary corpora played a fundamental role in recovering Catalan historical collective memory and identity. In particular, it focusses on two writers, Domènec Guansé and Vicenç Riera Llorca, in the light of recent studies of literary history, which have begun this process of re-evaluating the literature of exile, and thereafter relates their work to the theories of Lowenthal, Ricoeur and Traverso regarding the past and memory.
\end{abstract}

Keywords: exiled Catalan writers, Spanish Civil War (1936-1939), Francoism, exile of 1939, historical memory, Catalan identity, Domènec Guansé, Vicenç Riera Llorca

\section{The annihilation of memory and identity}

Catalan society is yet to fully and naturally incorporate its past into either the present or its projections for the future. However, as Lowenthal (1985) tells us, the past is single and unique and the various interpretations that may be made of it arise almost exclusively from human perception. For this reason, in the title of his book The Past is a Foreign Country, Lowenthal makes an assertion that concerns all of us regarding the action that we must take towards our collective memory: we have to know our past. Once we have done this, we can then preserve it, improve it, disfigure it or simply ignore it; we have to act on our past without lamenting it, we must learn about it through the memory, the history and the remains that it has bequeathed us. However, the Catalans as a people have been unable to fulfil Lowenthal's obligation (it goes beyond a mere right) because a large part of the population has been denied any opportunity to learn its own history at school. Paul Ricoeur identifies three types of memory depending on how it has been used and abused: impeded memory, manipulated memory and forced memory.

\footnotetext{
*Montserrat Corretger is Professor of Literature at the Department of Catalan Filology of the Universitat Roviri i Virgili and member of the Grup de Recerca Identitats en la Literatura Catalana (GRILC). Her research is mainly on contemporary Catalan literature, literary history and criticism - especially around the turn of the century, the 1920s and the 1930s, as well as the exile of 1939. Her latest books and articles are on Domènec Guansé, Vicent Riera Llorca and Odó Hurtado.
} 
The second of these terms refers to ideological manipulations of collective memory by those who hold power: "au service de la quête, de la reconquête ou de la revendication d'identitê" (Ricoeur 2000: 98). These types of ideological phenomena seek to make it seem that the authority held by those in power is a "pouvoir légitime de se faire obeir" (Ricoeur 2000: 101). Thus, the fragility of identity becomes an opportunity for the ideological manipulation of memory. The main element in the "ideologisation" of memory is, for Ricoeur, the narrative nature of the short story because the format always requires selection and coherence. And this mediating function of the short story transforms abuses of memory into abuses of the forgotten. Consequently, the short story provides strategies for forgetting and for remembering. In this sense, official history is an imposed memory because it is the one that is taught, "apprise, et célébrée publiquement" (Ricoeur 2000, 104). Catalonia has been trapped in this situation for 300 years and, since 1939, has been a victim of manipulated memory. ${ }^{1}$

Catalonia was forced to forget its past in two ways by the Franco regime: it was forced to forget its identity through the denial of its 1000-year-old history, its language and its culture; and it was forced to forget the control and repression of the State and how these were exercised over individual Catalans and their families after 1939, a long hiatus in the truth that has extended down to the current time and has led certain sectors of society to insist on their "right to know", which perhaps with some justification should be called the "obligation to know". And now we have reached the third stage in the evolution of memory put forward by Enzo Traverso on the basis of Henry Rousso's proposal: the "anamnesis" or "return of repressed knowledge" that "can lead to obsession with memory" after an initial traumatic event and a second phase of repression.

The "right to memory" leads to the expression "to come to terms with the past", which Traverso and Adorno regard as a mystification that tends to erase memory itself, and to the idea of "reconciliation", which rehabilitates the guilty. Catalonia currently finds itself in "the obsession phase [in which] the right to memory tends to become a rhetorical and conformist formula" (Traverso, 2006: 57-59). And this has been and still is the danger, i.e., the risk of institutionalising the study of memory in results of this exercise to the public. In a recent article, the historian Borja de Riquer describes how, in 1936, those who defended legality had democratic legitimacy on their side, but he finishes by lamenting that "there is still no shared memory regarding the meaning of the Second Republic, the Civil War or Francoism and that historical events are still manipulated with the aim of concealing responsibility" (De Riquer, 2016: 21).

The policy of the State, however, beyond the parties of government, has been to nourish the amnesia of the Transition $^{2}$ (a process that has been sold to the rest of the world as a shining example of peaceful change to a democratic system) and to continue the official repression of historical memory, with the result that various generations of Catalans and Spaniards are unaware of their immediate history (Traverso, 2006: 67). As Xavier Díez states, "the pact of silence imposed during the transition was a condition imposed by the victors in the civil war to enable them to continue their hegemony"; had it been otherwise, historical memory could have helped undermine the foundations of their power (Díez, 2006: 30-31). For decades, educational programmes dictated by the Spanish government have meant that the Spanish Civil War and the long dictatorship of General Franco have barely been studied in schools.

By the same token, the Spanish school curriculum has made no mention of the bloody repression, torture and humiliation of the one hundred thousand who disappeared, murdered by Franco, the thousands of political prisoners held for decades, or those forced to work for companies close to the regime or on public works, the most shameful of which is the Valle de los Caídos (the Valley of the Fallen), which still stands as a Fascist monument. Neither schools nor universities have given any attention to the planned genocide of Catalan culture. Successive generations have been left in the dark about the works of Catalan writers and, in particular, the works

\footnotetext{
${ }^{1}$ The section entitled "L'oubli", in the third part of the book, is devoted to historical condition and is used by Ricoeur to urge the individual to emerge from the minority, to create a story and to tell it himself [herself] because of the opportunity this gives to reclaim the capacity to narrate by certain social sectors and to assist each individual in discovering the memories of others who are able to create an intelligible and responsible account. In this manifestation of the forgotten, of manipulated memory, he proposes historiography as an effective discipline with categories taken from the psychopathology of the every day and the sociology of ideology.

${ }^{2}$ For more on "the novel of the transition" and "the story they have tried to sell us", see Fontana (2005, 121-142. Citation: 121). See also: Martínez (2014).
} 
of authors condemned to exile by Franco. This situation is likely to continue given the cursory treatment of this body of literature in secondary school curricula.

The repression of Catalonia was particularly bloody and expressed the Francoist regime's desire to annihilate any vestige of Catalan identity and any attempt at cultural revival. It was followed by systematic control during the period of so-called second Francoism, which began to supersede the monolithic cultural policies of the immediate post-war period (Pecourt, 2016: 359). This control was exercised until the 1960s by Falangism (the Spanish version of European fascism) and by the Catholic Church, which, by marginalising Republican cultural institutions and traditions, established a "Francoist culture". Subsequently, during the Transition, the Spanish Ministry of Culture continued to control the return to democracy and to reinterpret the past in favour of the political process that was then under way (Pecourt, 2016: 360,366), ${ }^{3}$ and to this day, the State continues to watch closely over the recovery and re-emergence of Catalan culture. Indeed, the politics of the Transition did allow for open recollection of the Civil War, but they ignored Francoism, a fact that can be laid squarely at the door of the regime and its policy on collective memory, which aimed to eliminate the memory of democracy, to erase all evidence of its own violence, to delegitimise and stigmatise the Second Republic (Traverso, 2006: 66), to make the regime seem like a historical necessity and to construct a false history of Spain that was in line with its political stance, a policy that has conditioned institutionalised collective memory throughout the second half of the 20th century and down to the present day (Molinero, 2004: 22-31).

Surprisingly, even today, the population remains largely unaware of the various actions and forms of repression carried out by Francoism. In a recent interview, the historian Josep Fontana commented on the deliberate silence surrounding the history of the Transition ("there were too many people to hold to account") and on the left wing parties' inability to finish off the Francoist regime, which in turn led to their decision to come to a consensus and allow the Republican period and its project to be buried. It is particularly important to retrieve this escaped memory of the cultural efforts made during the Republic, "if only to counter the gross act of pardoning Francoism with the false excuse of saying that the Republic was merely a quarrel between impassioned people".

The Law on historical memory (Law 52/2007, of 26 December) passed by the socialist government of Zapatero also fails to assist in the real recovery of the immediate past because it merely touches on certain specific aspects of a problem that needs to be sorted out at the root. For M. Dolors Genovès, the problem with this law on the "recognition and expansion of the rights of victims of the Civil War and the Dictatorship" is that it "insists on painting a benign picture of families that have both victims and tyrants among their members" (Genovès, 2006: 22). The pact of silence surrounding the Transition, that "erasing of memory by decree" (Díez, 2006: 31), was not broken by the 2007 law, and it has reached the point where efforts to save the record of the past are often transformed into an attempt to cloud what really occurred. ${ }^{5}$

The current governing party in Spain has led and continues to lead with complete impunity the policy to erase all recollection of the past, a policy openly discussed by high-ranking officials. Many times, the President of the Spanish Government has advocated the censorship of the past, and on many occasions, his words have been echoed by members of his own party. ${ }^{6}$ A veritable abyss separates this attitude of smoke and mirrors regarding the truth (hidden behind the Spanish State's feigned desire for reconciliation) from the situation in Germany, where, since 1991, the state has facilitated and subsidised the often-difficult process of bringing to light the

${ }^{3}$ Pecourt's study of relations between intellectuals and the Spanish State covers the period of so-called second Francoism up until 1992, a date that he regards as symbolic as it saw the culmination of the democratic cultural policies of the 1980s. See Rius-Ulldemolins and Rubio Arostegui, eds. (2016: 359)

${ }^{4}$ Fontana (2016). On the question of identity, see: Fontana (2005).

${ }^{5}$ Regarding policies of collective memory in Spain, see the essential text written by Paloma Aguilar Fernández (2008).

${ }^{6}$ One of the most recent and most flagrant examples of this is the declaration by the National Secretary for Health and Social Affairs of the People's Party, José Ignacio Echániz, who publically justified the government's refusal to subsidise the exhumations of the graves of people abducted and murdered by the dictatorship by saying "we have to close the wounds of the past" and that during the Transition, the decision was taken to establish a "social pact that looked to the horizon in order to forget the past. [...] Let us not open up new political fronts that will fracture Spanish society" (10-6-2016).

Available at memoriahistorica.org.es/videos/

For more information on these exhumations, see the website of the Association for the Recovery of Historical Memory (ARMH) at memoriahistorica.org.es/s1-news/c3-destacado/espana-la-memoria-enterrada. 
extent of the Stasi's infiltration into the personal and family lives of anybody that it wanted to investigate in the old East Germany. ${ }^{7}$ In an attempt to act before it was too late, some historians in Catalonia took advantage of the protection afforded by the Law on historical memory to begin work on various fronts to try to eliminate the situation of forced ignorance in which Catalan society has had to live for almost 8 decades. During the first years of the 21st century, researchers in the fields of history, sociology and politics started to disseminate their work extensively in what is perhaps the beginning of the Traverso's third stage of obsession. ${ }^{8}$ A symptom of this is the dossier entitled Història, Memòria i Identitat ${ }^{9}$ (History, Memory and Identity) published in 2006 by the journal Idees, prior to the Catalan government's creation of the Democratic Memorial in November $2007 .{ }^{10}$

Of particular note among studies on the recovery of memory and Francoist repression are those by a significant number of cultural historians, mostly specialising in literature, who - in the past 20 years - have uncovered literary works and political, cultural, epistolary and journalistic sources that bear witness to the extent of the Catalan diaspora in 1939 and the relations between exiled Catalans and Catalonia under Francoism. This research has provided a wealth of information on the Republican period, on how exiled intellectuals viewed the situation inside Catalonia and on their involvement in the complex debate surrounding the construction of the nation. In addition to works on the Civil War, the retreat, the trans-Pyrenean exodus, the concentration camps, the repression and censorship, ${ }^{11}$ there are important works on the activities of exiled writers, which were essential to sustaining Catalan culture and identity in connection with the core of resistance back in the homeland.

The research deals with writers, journalists and critics such as Rafael Tasis, C.A. Jordana, Francesc Trabal, Joan Oliver, Vicenç Riera Llorca, Domènec Guansé, Xavier Benguerel and Odó Hurtado, among others. ${ }^{12}$ These writers were able to return without having to be too fearful for their own safety, given the State's willingness to accept the return of exiled intellectuals (and thus try to assert its moral authority over these men and women) provided that they did not openly state their sympathy for subversive traditions or ideas or advocate the return of the Republic (Pecourt, 366). The exiled Catalans, however, did not belong to the group of well-known Spanish exiles and after 30 years, their names were almost forgotten in their own land. Perhaps for this reason, their literary creations in general went unnoticed, although they were still remarkable milestones in terms of historical recovery and the demand for recognition of Catalan identity.

Some examples of this are the novels of Riera Llorca, such as Fes memòria, Bel (Barcelona: Selecta, 1972, Sant Jordi Prize 1971), which dealt with the Events of October 1934, and Amb permís de l'enterramorts (Barcelona: Edicions 62, 1970, Prudenci Bertrana Prize), which alternates between the "present" of 1962 and a vivid and direct evocation of the retreat in 1939, the concentration camps and exile, and Odó Hurtado's novel Desarrelats (Barcelona: Selecta, 1963, finalist for the Sant Jordi Prize 1962), which tells the story of a visit to Catalonia in 1960 by a Catalan exile and his Mexican-born daughter. The daughter's experience is one of cultural and moral shock, while the father is no less perturbed to find that some of his old friends have been assimilated into the Franco regime. The novels use an imagination rooted in the experience of history to make up for the lack of information and the official distortion of history.

\footnotetext{
${ }^{7}$ See: Wunschik, T. "El papel de los Archivos en la defensa de los Derechos Humanos y de la Memoria Histórica. Los documentos del Servicio de Seguridad del Estado. Acceso a los archivos y recuperación a cargo del Comisionado Federal para los Archivos de la Stasi en la República Federal de Alemania". Available at www.fesmadrid.org/pages/publicaciones.php.

${ }^{8}$ See: Rovira i Vázquez (coord.) (2004) and AA.DD. (2004).

${ }^{9}$ Idees. Revista de temes contemporanis, 28-29, January/June 2006. Also, the dossier "La memòria perplexa", number 35, May/August 2012.

${ }^{10}$ See the institution's mission statement on its website at memorialdemocratic.gencat.cat/ca/memorial_democratic/qui_som. Their publications feature essential articles such as Enzo Traverso's "Dret, història i memòria". Quaderns del Memorial Democràtic, Barcelona: Generalitat de Catalunya, 2010.

${ }^{11}$ Regarding these questions, see the extensive bibliography by Francesc Vilanova d'Abadal and Maria Campillo.

${ }^{12}$ Among other studies, for Rafael Tasis, see Bacardí i Foguet (2012 and 2015); for C.A. Jordana i Francesc Trabal in exile, see Campillo (2009) and (2011b); for Joan Oliver in exile, see Busquets i Grabulosa (1999). For the writings in exile of Vicenç Riera Llorca, see Corretger (2014), Camps (2011) and Ferrer and Pujadas (2003). On Domènec Guansé in exile, see Corretger (2011). On Xavier Benguerel, see Busquets and Grabulosa (1995) and Casacuberta (2011). For writings in exile of Odó Hurtado, see Corretger (2016).
} 
The present article uses a couple of case studies as a model to describe how the recovery of memory functioned in the works of these exiled writers.

\section{The exiles' commitment to the recovery of memory and identity}

Literature has been a fundamental tool for denouncing the willingness to overlook the crimes of the dictatorship, the surveillance and control to which citizens were subjected as well as the censorship that restricted manifestations of Catalan culture after the end of the Civil War. Despite the recent wave of novels that deal with the post-war period, the first authors to rescue the personal testimonies and experiences of the war and the postwar period were the exiled novelists. They provided direct news of those dramatic events as well as of the political, social and cultural world of Catalonia before the war. They are, therefore, a broad and living portrait of Republican culture that is itself able to denounce the stigmatisation to which it was subjected by the regime.

The first writers to cross the frontier between 26 January and 12 February 1939 set in motion this recovery and process of national construction, and they did so immediately and freely, first from France and later from the Americas, although they faced great difficulties in getting their work published and distributed. Also contributing to this process were those who, after returning to Catalonia, wrote novels and studies in order to disseminate history and ideas under the watchful eye of the censor or during the first years of democracy. ${ }^{13}$ In the present study, as basic examples of this literary output, I choose the works of Domènec Guansé (1894-1978) and Vicenç Riera Llorca (1903-1991), with some references to the works of Odó Hurtado (1902-1965) and Rafael Tasis (1906-1966). From the 1940s onwards, their novels, depictions, letters and political and literary articles mark the way towards a "re-finding" of Catalan identity and a commitment to the right to build the present and the future over the foundations of their own history.

Currently, almost all those who witnessed the war and exile have gone, and we are left only with family memories. It is true that historical research into this period provides an academic understanding, but 21 st century literature, apart from notable exceptions such as the novels Les veus del Pamano (2004), by Jaume Cabré, and La sega, by Martí Domínguez, does not always paint an accurate picture. Faced with the danger of losing the records essential for rebuilding a despoiled collective memory, it becomes more necessary than ever to revisit or read for the first time the works of authors who left an account of these events. The general ignorance surrounding these novels and indeed the lack of subsequent reprints have ensured that they remain forgotten in the world of publishing. To amend this deficiency, society must urgently be provided with works produced in exile or under the mental condition of exile. The same can be said for essays published or written by the diaspora, such as Ciutadania Catalana (1957) by Manuel Serra i Moret or L'Estat Català (written in 1947) by Antoni Rovira i Virgili, works that are practically unknown today, despite their relevance and applicability. ${ }^{14}$

These authors wrote in exile after having enjoyed certain professional success in the 1920s and 1930s as cultural journalists in the Barcelona press (La Publicitat, Mirador, Revista de Catalunya, La Rambla, Meridià). During the diaspora, they continued their mission to inform, criticise and create. The model followed by these publicists and narrators continues to be valid today due to the intellectual vitality, modernity, desire for internationalisation and the quality of their writings, despite the difficulties times in which they began to surface. ${ }^{15}$

\footnotetext{
${ }^{13}$ It should be remembered that some writers, such as Mercè Rodoreda, never go beyond the 1930s, and almost transform them into a paradise lost. Others, such as Vicenç Riera Llorca, set their works in the 1930s and in subsequent periods up to their return to Catalonia, in addition to pondering on the nature of both external and internal exile.

${ }^{14}$ See: Serra i Moret (1957, [19782]) and Rovira i Virgili (2016).

${ }^{15}$ See: Campillo (1994) and Corretger (2008).
} 


\subsection{Domènec Guansé}

One of the most remarkable journalists and critics during the 1930s and thereafter was Domènec Guansé, who lived in exile from 1939 to 1963 and was committed to Catalonia and the Republican ideals that he had upheld while living in his homeland. ${ }^{16}$ In Santiago de Chile, he continued to write political articles, critical studies and intense novels, ${ }^{17}$ which he described as a vital and social expression of service to Catalan identity:

In short, my work as a whole in Chile was not intended to be a work of literary creation, but rather a body of texts that provided a service. [...] I was spurred on by the desire, shared by so many other exiled Catalans, to help give continuity to a culture, to a language in danger, to keep alive the flame of memory, to create a hope that could only take its strength from memory. (Riera, 1971: 55)

Guansé's ideology can be seen in his articles, wherein he defends Republican institutions and Catalan culture, where he calls for international intervention to overturn Franco's regime and highlights its illegitimacy, to turn the attention of exiled Catalans to the situation back home and, above all, to raise awareness of writers committed to Catalonia and to use history to drive the present. Of all these ideological ideals, he was most passionate about using recent history to guarantee the future, to provide a model for both individuals and society as a whole. For this reason, just as his teacher Rovira i Virgili had done, Guansé taught using historical events, which he described with a stirring vitality, particularly those that he had experienced firsthand. Within this historical account, he included the memory of cultural, literary and social achievements during the Republican period and opinions regarding hopes of liberty for Catalonia after the Allied victory in 1945 and Catalonia's damnation due to international non-intervention against Franco's government. He denounced the exclusivist positions held by some members of the exiled community (economic migrants) and defended the political and social commitment of writers in articles of literary criticism. These were recurring ideas that filtered through even to his narrative works and were articulated by his literary imagination.

He was concerned about the survival of Catalonia during the initial post-war period, a burning topic that he considered more serious than the problems of exiled Catalans. It is for this reason that he wrote an article in Germanor entitled "Life in modern Barcelona", in which he highlights the moral and economic misery of the city that the "Caudillo" had visited against the backdrop of the war in Europe. His description of this social malaise included not only the working and middle classes, but also industrialists, landowners and the clergy: "Yes, everyone is unhappy, disillusioned, with empty stomachs and sadness in their souls" (Guansé, 1942a: 1114). In the article "To Catalonia", he focussed on the precarious situation in the Principality of suffering, hunger, humiliation, shame, which - contrary to the Regime's intentions - united the Catalans against Franco. Above all, he expressed the desire for sovereignty that Catalonia would demand once it was free from the dictatorship: "No, Catalonia will not bow before any regime, however republican it says it is, before any regime that wants to keep it in chains".

He outlines the only possible path towards dignity, the fruit of his historical experiences and the doctrines of Rovira i Virgili: "Catalonia wants to be the master and sovereign of its own destiny, just like any other people, and only once it has achieved this dignity and equality will it be able to have proper relations with the other peoples in the Iberian Peninsula or Europe" (Guansé, 1942b: 16-17). In November 1940, he began the first of a series of historical works with "The political life of Lluís Companys", an essay in which he combines the vividness of a novel and journalistic exactitude to recount the political events involving the last president of free Catalonia, in particular, the 6th of October 1934, the Civil War and the subsequent exodus. He concluded that Companys's sacrifice would contribute to the "future resurrection" of Catalonia, a key idea that guided refugees during the first year of exile (Guansé, 1940: 8-13). In his commitment to preserving the collective memory as the only guarantee of historical continuity, in "Culture in autonomous Catalonia", he outlines the aim of saving the legacy of writers and the cultural work carried out during the 1930s:

Autonomous Catalonia had reached a point of maturity in many cultural aspects and in many of its institutions, and that was an incentive for the aggressors. Today, motivated both by personal desire and

16 On Domènec Guansé, see Corretger (2011a).

17 See: Corretger (2011a: 133-203) and (2011b). 
a wish to bear witness to those who are unaware, I propose to make a panoramic evocation, albeit limited by my own limitations, of those times and of spiritual life in Catalonia. (Guansé, 1942c: 10-13)

In starting a series entitled "Portraits of Catalan writers", he states that his decision to commemorate is motivated both "by the pleasure of bringing writers to the attention of a Catalan public that is almost completely unaware of them and to others who had neglected or forgotten them" and "by the wistful gratification that comes through the evocation of the past", although he does concede that his efforts are hampered by his constant lack of materials: "I do not have to hand any of the principal works by these authors with which to refresh my memory". These evocations provided the stimulus for action in the present and were centred on authors such as Josep M. de Sagarra, Carles Soldevila, Miquel Llor, Carles Capdevila, Jaume Bofill i Mates, Just Cabot, Antoni Rovira i Virgili, Prudenci Bertrana, J. V. Foix, Puig i Ferreter and Josep Carner, a list that in 1947 would become the nucleus of the book Literary portraits (Guansé: 1943 and 1944). Published in Mexico, it is the study in which Guansé most clearly expresses his desire for the political and cultural recovery and projection of Catalonia. $^{18}$

Guansé was also committed to spreading political ideas; in a letter to Rafael Tasis in 1958, he comments on his surprise at realising that his notion of Catalonia is disconnected from contemporary reality and on his perception that those in American exile are drifting ever further away from life in Catalonia. He makes this confession in regard to a talk that he had given:

I wrote it without any pretensions for some meetings that we hold from time to time to pass the time in a patriotic manner. Some of my friends liked it and asked me to translate it into Spanish for publication. [...] I suppose it is a utopian wish, but I tried to write something that was not so far Catalan reality and Hispanic reality, as is often the case with things written in the Americas. But for me Catalonia is now so far away in time and distance $!^{19}$

He wrote this study, "Catalonia in the Hispanic enclosure", at the request of the Catalan Cultural Institute of the Catalan Centre in Santiago and with the intention of describing the situation in Catalonia 20 years after the war. ${ }^{20}$

Once he had returned to Barcelona, Guansé continued to feel alienated from Catalan society "both inside and out, I still regard myself as an exile",-- ${ }^{21}$ but he quickly got on with the work of recovering the collective memory and culture. By no means did he enjoy a privileged existence: with Franco now gone and hopes of a new political landscape, at the age of 82 , he wrote for Ofèlia Fernández an illustrated evaluation of both forms of exile, external exile and resistance under the regime, which is worth reading in its entirety: ${ }^{22}$

As you say, the conscience of the Catalans has not gone to sleep. The same cruel, vexing and stupid nature of the persecution has kept alive the feeling of Catalaness, at least among the most sensitive spirits. You only have to recall the two lines by Carner in the suite of sonnets "L'altre enyor" [The other longing] in reference to Catalonia: "I know that you must be radiant/it would be bad if I alone paid homage to you". And, of course, he was not the only one. As soon as they arrived in Paris, Catalan exiles resumed publication of the Revista de Catalunya [Journal of Catalonia], just as they had done a

\footnotetext{
${ }^{18}$ In 1966, a second and modified edition was published with the title "Abans d'ara", Barcelona: Aymà. A second edition of d'Abans d'ara was published in Tarragona by El Mèdol (1994), introduced and edited by Josep Bargalló Valls. For unpublished portraits or versions not included in the works from 1947 and 1966, see Corretger and Foguet (2015).

19 Letter from Domènec Guansé to Rafael Tasis, 21-VI-1958 (among the letters cited between Tasis and Hurtado: Rafael Tasis Archive [Hemeroteca UAB] and Víctor Hurtado Cuevas Archive). The talk, given in Catalan, was published under the title "Cataluña en el ruedo hispánico" in 1957 by the Catalan Cultural Institution of Santiago. News article in Ressorgiment, 489, Buenos Aires, Abril, 1957, p. 7885.

${ }^{20} \mathrm{He}$ discussed ideas such as the elimination of political parties and creating an organisation that would act above party interests; the countries that make up Catalan nationality; federalism and confederation; the problem of a permanent army; the understanding between Catalonia, the Basque Country and Galicia, and the legality and symbolism of the Catalan Government in exile: Corresponsal [s/s]: "Taula rodona, entorn de la tesi de D. Guansé: carta de Mèxic", Ressorgiment, December, 497, Buenos Aires, 1958, p. 8013.

${ }^{21}$ Letter to Ramon Fabregat, in Mexico, dated 10/7/67. Collected Letters D. Guansé: Guansé Archive. [F.G.] National Archive of Catalonia. [ANC]. The letters cited come from this source, unless otherwise stated.

22 Ofèlia Fernández i Ardiaca. See: DD.AA. Diccionari dels catalans d’Amèrica, p. 214.
} 
short time previously in Barcelona. In Argentina, Catalans acted quickly to found a publishing house and reinvigorated the journal Catalunya which had been published there for a while. I resumed publication of the journal in Toulouse after having worked on it in Barcelona. You know plenty about the work done in exile, I don't need to say much more about it. It should be recalled that two of the most important works in modern Catalan literature were published in exile: Nabí by Josep Carner and the Elegies de Bierville by Riba, the latter published for the first time in Santiago de Chile by the Pi de les Tres Branques publishing house. You may say that Exile was Exile and that in Catalonia the experience was entirely different. Don't believe it. First, the things that were achieved in exile had far more impact in Catalonia that is generally believed. However, in Catalonia the process started early with notable journals such as Ariel published more or less clandestinely. They were forced to fold, but in 1945, I don't remember the exact date, I received the first pamphlets of university poetry in which 25 or 30 authors, all debutants, had collaborated. The pamphlets were sent to me by a student who I didn't know. In terms of the quality of the poetry, the texts were of little value; however, the important thing was that they were linguistically sound. This means that there was a nucleus of intelligent students at the university who were working to keep the language alive. We didn't have to wait long (1946) for the regular publication of new books in Catalan through the creation of various collections by the Selecta publishing house. A the same time, the flame was kept burning in Mallorca with the publication of the Diccionari Català-Valencià-Balear [Catalan-Valencian-Balearic Dictionary], a mistaken title but one which the circumstances warranted, given that in reality its eight or ten volumes constitute a Catalan Dictionary featuring all of the language's dialectal variants. Finally, the work of Catalanization continued in Valencia and culminated with the publication of Nosaltres, els valencians [We, the Valencians] by Joan Fuster, which won an award at the last Jocs Florals in Santiago de Chile. All of this means that the difficulties are not limited solely to Catalonia, but rather when language and culture are discussed, there are constant references to the "Catalan Countries", which include even Roussillon, or Northern Catalonia as it is now called. You know all of this just as well as I do, but it is worth reminding ourselves of it, because they are all factors that allow us to better understand the current situation. ${ }^{23}$

\subsection{Vicenç Riera Llorca}

In the years subsequent to his return to Catalonia in 1969 after exile in France (1939), Santo Domingo (19401942) and Mexico (1942-1969), Vicenç Riera Llorca reflected deeply on literature as an activity in the service of recovering a past identity that, even in 1977, had still not been officially recognised. In parallel with this, the years of dictatorship had had the direct result of causing a breach in Catalan literary production, which Riera proposed to redress by bringing recognition to the activities of writers who had lived in exile. He believed that they could help to unite the generations separated by the gaping chasm of the Franco regime: "The narrative produced in exile and during the immediate post-war period is gradually filling the hole that has been created, the gap that was created between narrators, novelists and short story writers established before the war and the young writers of today" (Riera, 1977: 16).

It is clear that Riera's work, which includes 13 novels and two collections of short stories, principally aims to help fill this space, in which a new contemporary school of writing, "mostly produced by young writers" (Riera, 1977: 16) was also debated. On several occasions, Riera demonstrated his desire for writers of his generation to fill the breach in Catalan literary production in order to prevent the risk of "a period in Catalan life remaining undocumented or defined; namely the period from 1936 up to an imprecise and recent date" (Riera, 1977: 16). During a conference in Tarragona on 15 December 1981, he repeated his view that exiled Catalan writers were governed by an "overriding literary imperative; they knew that Catalan literature was undergoing a rupture in its natural environment" and saw themselves as the "repositories of the written language" in that time of great difficulties. For this reason, they continued to write in Catalan, despite knowing that their potential audience was very small (Riera, 1981).

This sense of redressing history through literature also impregnates Riera's own work, which was published after 1970 . He believed in the need to produce the literature that should have been created during the period of extreme vigilance by the regime:

${ }^{23}$ Letter from Domènec Guansé to Ofèlia [Fernández] (Santiago de Xile), dated 2 June 1976. 
It is not a question of giving literature a didactic or informative role so that we can produce a retrospective picture of the lives and character of the Catalans both here and in exile, but rather of creating that literature which was not produced, that would have been produced and that still needs to be produced without being too anachronistic, because those who need to undertake this task can take themselves mentally and emotionally back to when the events occurred and to the emotions that they experienced, and transform all this into literature. (Riera, 1977: 16)

Riera also insists on the importance of narratives focussing on war and exile because "we cannot leave thirty years of Catalan life without the literature that it needs" (Riera, 1977: 16). In 1962, he used the literary journal Serra d'Or to list a series of works published by writers in the Americas after 1939, with the aim of "giving the readers [...] an idea of the volume of work" (Riera, 1962: 31). It is the first comprehensive overview of the literature produced in exile and is a historical record that directly opposed the deliberate programme of eradication implemented by the regime. He discusses these objectives in his letters to Domènec Guansé:

After Tots tres surten per l'Ozama, my novels follow a set plan that aims to describe the atmosphere in Catalonia, or more exactly Barcelona, from 1931 to 1936. Then they will deal with life in exile, which I experience. And if I manage to do all this in twenty volumes (don't think that I am getting carried away, in addition to seven novels already published, I am on the point of finishing and publishing another four and am thus already halfway through the task) I will branch out to deal with modern Catalonia.

My emphasis on life in exile is motivated by the fact that there were so many exiles and that consequently, what they did whilst outside Catalonia, whether good or bad, is a part of Catalan life and must therefore have its own literature. I am making my own contribution. I am not the only one to give an account of that life. There are the books of Calders, Ferran de Pol, Jordana, etc. It may be said that exile was as I describe it, but it was also other things. I would agree with that. I explain from my own point of view (Pineda de Mar, 23-10-1975).

All of Riera's work, both narrative and journalism, is devoted to recounting the period of exile, even though only three novels, Tots tres surten per l'Ozama (Mèxic: Catalònia, 1946) and Roda de malcontents (Barcelona: Cadí, 1968), were written in Mexico. To achieve his goal, Riera opted for documentary-style literary realism. The need to bear witness to an unchronicled period and to explain events that were not explained at the time pushed him in the direction of this style of narrative, which he used to express political thought and the defence of social rights and national identity from his time in the Catalan Socialist Union (USC) ${ }^{24}$ during the 1930s and, when he went into exile, in the Socialist Regroupment founded by Josep Pallach. ${ }^{25}$ The novel in which Riera's desire to rescue the collective memory is most evident is Fes memòria, Bel, which focuses on the events of October 1934 and is narrated as an eyewitness account, an almost cinematographic tale of events that were consigned to obscurity during the dictatorship and that even now most of the Catalan population would be unable to describe.

The historicism in Riera's writing demonstrates his conviction that literary fiction is often more expressive than scientific rigour when it comes to giving an impression of particular historical moments and events. His work is an agent provocateur for memory that uses literature to provide reliable data for historical interpretation. Consequently, Riera's novels have to be read for their narrative values, which underline their validity as documents. Artistic quality is not, however, a secondary consideration for Riera, given that in order to achieve this effect, he uses objectivist techniques learnt from American writers in the 1930s and which he pioneered in Catalonia. Such techniques include fragmentation, alternating between narrative voices, simultaneity or the juxtaposition of scenes, among others. His effortless handling of these resources and the mastery with which he

\footnotetext{
${ }^{24}$ Despite his membership of the USC, he became disillusioned with the party's attitude towards the war and exile. Hence, in the novel Què vols, Xavier? (Barcelona: Nova Terra, 1974) he has one of his characters say "I got tired of inhuman discipline, of the contradictions and of being told what I have to think" (p. 145). In Oh, mala bèstia! (Barcelona: Nova Terra, 1972), another character, a union leader and socialist in Barcelona complains about the USC's merger with other parties within the Unified Socialist Party of Catalonia (PSUC): "I can no longer identify with a political organisation that has changed so much and I have left it. During the war I had no option but to respect the new discipline and adapted my attitude to the circumstances. I didn't want anybody to confuse me with those who have gone soft under the easy life that Mexico offers, but I seriously didn't know what kind of political work I could do" (p. 10).

${ }^{25}$ On his return, Riera's commitment to socialist ideals led him to join Josep Pallach's Socialist Regroupment. See: AA.DD, Diccionari Biogràfic del Moviment Obrer als Països Catalans, p. 1166.
} 
instils an overarching continuity to his body of work today arrest the attention of the reader, who in reading Riera's novels moves without any impediment back and forth between memory and fiction.

\subsection{Aspects of exile: the return, the letters and censorship}

The culminating moment in the struggle of these exiled Republican authors comes when they assert their identity and that of the nation when they return to Catalonia. Novels and essays by Riera Llorca, Guansé and Odó Hurtado highlight the problems facing the exile and his family on returning to the homeland. It is not only a problem of a social, economic or emotional lag, but also of identification with a world that no longer corresponds to the nation that they left behind, a fact that leads to doubts about belonging. This problem is accompanied by a feeling of moral and cultural distance or alienation when attempting to reintegrate into a society that had been assimilated by the Regime. Hence, Domènec Guansé's description of his uneasiness in a letter to Albert Junyent, resident in Paris, dated 16 November 1969:

For my part, I continue to frequent these places that, contrary to what you imagine, I find every day to be more infected. I feel like returning to Chile. But no, I won't do it because I can't be bothered to get in a vehicle. Got to Paris? Thanks, but don't even think about it! If I knew I could stay there, I might entertain the possibility. Since that is not possible, the curtain will fall ineluctably on my final act in Barcelona or its surroundings. It don't like it, but it doesn't matter.

In his unpublished novel L'estrangera (1956) and the short story Confessió d'un emigrat (1943), Guansé transforms the subject of returning into highly nuanced narrative material. ${ }^{26}$

In Riera Llorca's case, in addition to historical information, the novels deal with burning questions such as the concept of exile and the condition of the exiled individual; the various attitudes adopted by refugees in Mexico and the resulting socioeconomic groups; the changes in individual political views; the various personal perspectives on Mexican society; the situation in Catalonia; and the fundamental question of the decision to return. The possibility of returning becomes Riera's central preoccupation in his novels and in his editorials for Pont Blau, the journal that he directed in Mexico from 1952 to 1963 . It is a theme that emerges from his reflections on the unity among Catalans beyond the places where they live. In Joc de xocs (Barcelona: Alfaguara, 1970), one can read an illustration of this idea:

Reixac has condemned the notorious tendency among refugees to distinguish between Catalans in Catalonia and those in exile and has stated that Catalans are all one and the same, wherever they are, and that the work and conduct of exiles, of each one in his particular field of work, is as Catalan as that of those who have never left the country. (1970: 104).

The subject of returning is related to the demythification of the political value of exile and the moral obligation on those living abroad to work for the nation: "those whose seek to continue their political activities have the greatest obligation to return, come what may", he says in Tornar o no tornar (Barcelona: Laia, 1987, p. 64). And he further synthesises these opinions by making one of the most lucid characters in the novel say "the political strength of the Catalan people is the country, the exiles, being temporarily displaced, have no right to continue to believe that they are key elements in this and that sooner or later the situation will return them to power" (p. 118).

The letters between the diaspora and the homeland also discuss questions and can be used to create an overarching map of the memory of exile given their status as the largest spontaneous work of collective memory in the 20th century history of Catalonia. The wealth of information in the letters facilitates the reconstruction of the links between the 1930s and the 1980s. Together, they provide a complete picture of cultural, social and politic ideas and events after the exodus. Some of these letters by Tasis, Guansé, Riera and many other writers and politicians have been published or are in the process of publication; these also include letters sent to and from France and others that are being turned up in the Americas and published in collections or research

\footnotetext{
${ }^{26}$ Domènec Guansé, Confessió d'un emigrat, Catalunya, 157, Buenos Aires, December 1943, pp. 33-37. Regarding both works, see Corretger (2011 and 2011a).
} 
articles. ${ }^{27}$ In the book Nou obstinats by Riera Llorca, Guansé strongly argues for the publication of letters written in exile because "in certain regards the best literature produced in exile was in letter form" (Riera, 1971: 54). The large quantity of surviving letters allows us to understand the political, social and personal worlds of Catalan intellectuals during these crucial years and to evaluate their efforts in the construction of national identity through the constant exchange of correspondence.

The wealth of shared and mutual interests stimulated the authors to maintain their activities both in exile and on return. The letters' interest derives from the fundamental themes that preoccupy them: the effect of exile on the authors and the responsibilities of these in their relations with Catalonia; the doubts and efforts regarding a new personal and professional life in Catalonia; and the continuity of their literary careers once they return. The identity crisis caused by returning to the homeland is reflected in letters, articles, essays and creative texts. Vivid examples are novels such as Amb permís de l'enterramorts and Tornar o no tornar by Riera, Desarrelats by Hurtado and L'estrangera by Guansé. A fundamental question for all of these authors was the possibility of living as professional writers in Catalonia (despite the control of the censor), receiving the attention of readers "back home" and participating in literary prizes.

The letters between Odó Hurtado and Rafael Tasis and those written by the former to Josep Cruzet and Tomàs Tebé (directors of the Selecta publishing house) are very rich in information and constitute reflections on these questions. ${ }^{28}$ They represent continuous epistolary relations that demonstrate combative and often contradictory attitudes towards the censor, the complex world of literary prizes, the efforts to circulate their work anonymously and the need to adapt to a public that, despite being Catalan, was alien to them and unprepared to receive certain subjects and ideas. Through these letters, we can observe feelings such as the fear of being excluded from literary competitions for being regarded as a "red", even among writers resident in Catalonia but who were immersed in the conditioned society of the Regime.

This feeling was shared by Guansé, Hurtado and even some of their literary characters, a fact that demonstrates the continuum between reality and fiction with regard to the representation and censure of these highly charged questions of identity. ${ }^{29}$ Thus, in relation to the distribution of his work in Catalonia, Hurtado questions his own name, that of a politically tainted refugee, "a red", the same name that is given to the protagonist of his novel Desarrelats by supporters of the Regime (p. 46). For the same reason, when - in 1956 - one of his short stories becomes a finalist for the Santamaria prize, he casts doubt on the likelihood that it will ever be published, confessing to Tasis: "If they don't let it through it will prove that the real obstacle is the author's name and, if nothing else, at least we will know just how things work and that it is not worth making any further attempts" (to Tasis on $16 / 9 / 56)$.

References to surveillance and persecution are constant in the letters of exiles when they talk about their contacts and a possible return to Catalonia. Aside from the censor, one of the main obstacles to continuing their career as writers is the difficulty in adapting to the moral regime that dominates it. It is a recurring theme in the letters between Hurtado and Tasis, for instance, the one dated 15 October 1957, in which Hurtado discusses his chances of winning the Joanot Marorell prize with Es té o no es té: "the subject matter is discussed in a manner that is

\footnotetext{
${ }^{27}$ I cite only some examples of works on the letters of these authors: La cultura catalana en el primer exili (1939-1940). Cartes d'escriptors, intel-lectuals i científics (Campillo i Vilanova, 2000), Pere Calders/ Rafael Tasis (Bacardí i Foguet, 2013), Rafael Tasis/ Ramon Xuriguera (Camps Arbós, 2010), Joan Oliver/ Xavier Benguerel (Busquets Grabulosa 1999), Riera Llorca/ Guansé (Corretger, 2013), Hurtado/Tasis (Corretger, 2016). The extent of the diaspora clearly provides plenty of scope for many more studies of this nature.

${ }^{28}$ Josep Maria Cruzet Archive, 1919-1997, National Library of Catalonia.

${ }^{29}$ Joan Oliver, in a letter to Xavier Benguerel, confirms one of the hypotheses that Guansé defended during exile, i.e., established and revered writers in Catalonia marginalised the works of exiles. In terms of literary prizes, this lack of interest led to exiled authors simply being passed over, as is confirmed by Oliver when discussing Guansé's chances of winning a prize for his novel L'últim retrat: "Guansé's situation is as follows: they will not give him the prize (it is said) because he is... an exile! The same nearly happened to you last year. Do you remember? It was lucky that you were here at the time. But now they will be thinking: the last thing we need to do after awarding a prize to that red, Benguerel, is to award another to that red Guansé. This is the rumour that is going around. That doesn't mean that at the last minute they won't change their minds". Letter from Joan Oliver to Xavier Benguerel at the end of November 1953 (Busquets i Grabulosa, 1999: 479-480).
} 
perhaps too free and raw for the prevailing atmosphere, given that whereas in Paris or New York the book would merely be regarded as a romance novel, in puritanical Barcelona it is regarded as scandalous, and even more so because it is written in Catalan". Shortly afterwards, in a letter dated 31 December 1957, he repeats his doubts that the Barcelona society of the 1950s will ever give him a warm reception:

I don't think that I will be putting anything forward for the Santamaria prize this year. [...] The only thing I have deals with a subject that is too delicate given the current sensitivities in Barcelona and I don't think it would be a good idea to send it. The jury is clearly more open-minded than that of the Martorell prize, even so I think the book will raise some hackles and it is not worth doing this for the sake of it.

This contrast between the mind-set of the exiles (who were mentally rooted in the Republican years) and that of those who were living under Francoism also appears in Desarrelats (pp. 235-236), at times with a certain attitude of superiority on the part of the former with regard to the latter's perceived lack of willingness to struggle for political reconstruction. Riera tenaciously fought against this in his editorials for Pont Blau, in articles such as "El problema de l'exiliat català" (Riera, 1967) and in his review of Hurtado's novel Desarrelats (Riera, 1965).

Similarly, Tasis, despite living in Barcelona, was well integrated into the world of exile through his journalism and written correspondence and, with his characteristic lucidness, was well aware of the limitations of the literature produced in Catalonia, these being made all the more stark by the works of those writing in exile. He highlights this difference in his review of Unes quantes dones by Hurtado in Pont Blau (1956: 30), where he describes the author as follows:

a Catalan narrator free of all the complexes and external and internal censorship that act as a brake on the pens of those of us who have to write and publish in Catalonia. We can see the extent to which we have limited the scope of our literary experimentation, the extent to which, initially due to external pressure and then due to a force of habit that has become almost natural, we have excluded all sorts of themes, implications, influences and realities that are present in the free literatures of the world but which are absent from our own at the current time.

The actions of the writers in exile embodied a real historical awareness of the nation's past and were motivated by an understanding of the need to leave their version of the events that they lived through in order to counter the official version of history that over the years eliminated the past by selecting only that which suited its political needs. In reading these writers, we become aware of their commitment to political and literary thought and of the strength of their creativity, which still remains largely unknown despite being a part of Catalan cultural heritage and, therefore, of Catalan identity. It goes without saying that recovering these writers and their works will help to bring back to life a past that to a large extent still remains in obscurity.

Acknowledgements. This study is part of the research carried out by the Universitat Rovira i Virgili's research group Identitat Nacional i de Gènere en la Literatura Catalana and the Grup de Recerca Identitats en la Literatura Catalana (GRILC) (2014 SGR 755).

\section{References}

AA.DD: Diccionari dels catalans d'Amèrica. Contribució a un inventari biogràfic, toponímic i temàtic, vol II. Barcelona, Curial Edicions Catalanes/Generalitat de Catalunya, 1992.

AA.DD: Diccionari Biogràfic del Moviment Obrer als Països Catalans. Barcelona: Edicions de la Universitat de Barcelona \& Publicacions de l'Abadia de Montserrat, 2000.

AA.DD: Identitat local i gestió de la memòria. Barcelona: L’Avenç, 2004. 
Aguilar, P.: Políticas de la memoria y memorias de la política. Madrid: Alianza Editorial, 2008.

Bacardí, M. and Foguet, F.: Les raons de l'exili. Valls: Cossetània, 2012.

Bacardí, M. and Foguet, F.: Pere Calders. Fe de vida. Cartes a Rafael Tasis. Barcelona: A Contra Vent, 2013.

Bacardí, M. and Foguet, F.: El revulsiu del catalanisme.Valls: Cossetània, 2015.

Busquets, Ll., Benguerel, X.: La màscara i el mirall. Barcelona: Publicacions de l’Abadia de Montserrat, 1995

Busquets, L1., Benguerel X.,/Joan Oliver: Epistolari. Barcelona: Proa, 1999.

Cabré, J. Les veus del Pamano. Barcelona: Proa, 2004.

Campillo, M.: Escriptors catalans i compromís antifeixista (1936-1939). Barcelona: Publicacions de l'Abadia de Montserrat, 1994

Campillo, M. and Vilanova, F. (cur.): La cultura catalana en el primer exili (1939-1940). Cartes d'escriptors, intel·lectuals i científics. Barcelona: Quaderns de l'Arxiu Pi i Sunyer, 4, 2000, p. 26.

Campillo, M.: «Cèsar-August Jordana. El món de Joan Ferrer». Quaderns: Revista de traducció, 16 (2009): 2942.

Campillo, M. (ed.): Llegir l'exili. Barcelona: L'Avenç, 2011a.

Campillo, M.: Edition and foreword of Francesc Trabal, Els contracops de l'enyorança. Escrits d'exili. Sabadell: Fundació La Mirada, 2011b.

Camps, J.: L'espantós és el buit, el desert. La correspondència entre Rafael Tasis i Ramon Xuriguera. Barcelona: Publicacions de l'Abadia de Montserrat, 2010.

Camps, J.: «Entre la crònica i la ficció. El món de l'exili a les novel·les de Vicenç Riera Llorca». In: Campillo, M. (ed.). Llegir l'exili. Barcelona: L'Avenç, 2011, pp. 85-101.

Casacuberta, M. «Els vençuts, de Xavier Benguerel: novel·la, crònica, història». In Maria Campillo (ed.). Llegir l'exili. Barcelona: L'Avenç, 2011, pp. 102-134.

Corretger, M.: Escriptors, periodistes i crítics. El combat per la novel·la. Barcelona: Publicacions de 1'Abadia de Montserrat, 2008.

Corretger, M.: Domènec Guansé, crític i novel-lista: entre l'exili i el retorn. Barcelona: Publicacions de l'Abadia de Montserrat, 2011a.

Corretger, M.: «Art i compromís: la narrativa d'exili de Domènec Guansé». In: Maria Campillo (ed.). Llegir l'exili. Barcelona: L'Avenç, 2011b, pp. 237-261.

Corretger, M.: «Cartes entre Vicenç Riera Llorca i Domènec Guansé (1966-1975)», Els Marges, 99 (2013ª): 6089.

Corretger, M. and Foguet, F.: Domènec Guansé. Catalunya a l'exili. Valls: Cossetània, 2013b.

Corretger, M.: «La narrativa de Vicenç Riera i Llorca: literatura i consciència històrica», Caplletra. Revista Internacional de Filologia, 57 (2014): 9-33.

Corretger, M. i Foguet, F.: Domènec Guansé. Retrats d'exili. Barcelona: Adesiara, 2015.

Corretger, M.: «Odó Hurtado: compromís literari des de l'exili». In: Montserrat Corretger, Pompeu Casanovas, Vicent Salvador (eds.). El compromís literari en la modernitat. Del període d'entreguerres al postfranquisme (1920-1980). Tarragona/Melbourne: PURV/RMIT, pp. 119-144. DOI: 10.17345/9788484244455.

De Riquer, B .: «La memòria dividida del 36», La Vanguardia, 2016, p. 21, (July $28^{\text {th }}$ ). 
Díez, X.: «Imaginaris contraposats. La doble memòria del franquisme i la transició. Ruptures catalanes respecte de la història oficial», Idees. Revista de temes contemporanis, 28-29, January/June (2006): 28-47.

Domínguez, M. Les veus del Pamano. Barcelona: Proa, 2015.

Ferrer, J. i Pujadas, J. (cur.) Vicenç Riera Llorca: Cròniques americanes. Articles publicats en les revistes de l'exili. Barcelona: Fundació Pere Coromines, 2003.

Fontana, J. [entrevista] In Aragay, Ignasi: «El debat històric. Josep Fontana. Historiador», Ara, Dossier, pp. 6-7, (August 14), 2016.

Fontana, J.: La construcció de la identitat. Reflexions sobre el passat i sobre el present. Barcelona: Base, 2005.

Garcia, J. V.: Lluís Ferran de Pol i Mèxic: Literatura i periodisme. Barcelona: Publicacions de l'Abadia de Montserrat, 1998.

Genovés, M. D: «Vindicació dels botxins per a una política del perdó», Idees. Revista de temes contemporanis, 28-29, January/June (2006): 15-27.

Guansé, D.: «La vida política de Lluís Companys», Santiago de Xile, Germanor, 451, November, (1940): 8-13.

Guansé, D.: «Com es viu actualment a Barcelona», Santiago de Xile, Germanor. Revista dels catalans a Xile, 464-465, January/February (1942 $)$ : 11-14.

Guansé, D.: «A Catalunya. L'esperit de revolta creix sota el fuet del dolor i de la fam, entre les humiliacions i la vergonya. Un sol sentiment uneix tots els catalans», Santiago de Xile, Germanor. Revista dels catalans a Xile, 466-467, March/April (1942b): 16-17.

Guansé, D.: «La cultura en la Catalunya autònoma», Santiago de Xile, Germanor, 471, August, (1942c): 10-13.

Guansé, D.: «Els meus contemporanis. Retrats d'escriptors catalans», Santiago de Xile, Germanor. Revista dels catalans de Xile, 481, September, pp. 11-15, 1943; 482, October, pp. 13-15, 36, 1943; 484, December, pp. 1518, 1943; 486, February, 1944.

Lowenthal, D.: The Past is a Foreign Country, Cambridge University Press, 1985.

Molinero, C.: «Memòria i silencis sobre la guerra civil i el franquisme durant la transició». In: Rovira, Marta $\mathrm{i}$ Vázquez, Fèlix (coord.). Polítiques de la memòria. La transició a Catalunya. Barcelona: Pòrtic, 2004.

Pecourt, J.: «Las políticas de la consagración intelectual en España (1960-1992)». In Rius-Ulldemolins, Joaquim i Rubio Arostegui, Juan Arturo, eds. Treinta años de políticas culturales en España. Participación cultural, gobernanza territorial e industrias culturales. Universitat de Valencia, 2016, pp. 359-374.

Ricoeur, P.: La Mémoire, l'histoire, l'oubli, Paris: Seuil, 2000.

Riera, V.: «Aspectes de la literatura catalana a Amèrica», Barcelona, Serra d'Or, 22 (1962): 29-32.

Riera, V.: «Desarrelats a fora i a dins» [about Desarrelats, d'O. Hurtado], Mexico, Xaloc, 6 (1965): 52.

Riera, V.: «El problema de l'exiliat català». In Revista de Catalunya, September,106 [Mexico], (1967): 71-75.

Riera, V.: Nou obstinats, Barcelona: Selecta, 1971.

Riera, V.: «Del dir i del fer. A cada temps, la seva literatura», El Poble Català, 0, Barcelona, January, 1977, p. 16.

Riera, V.: «La literatura catalana a l'exili (Mèxic)», lecture at the Museum of Modern Art in Tarragona, December 15 (notes: author of this article), 1981.

Rovira, M. i Vázquez, F. (coord.): Polítiques de la memòria. La transició a Catalunya. Barcelona: Pòrtic, 2004. 
Rovira, M.: La Transició franquista. Un exercici d'apropiació de la història. Barcelona: Pòrtic, 2014.

Rovira, A.: L'Estat Català. Xavier Ferré Trill (cur.). Tarragona: Publicacions de la Universitat Rovira i Virgili, 2016.

Serra, M.: Ciutadania catalana: breviari de cogitacions, remarques $i$ orientacions per als catalans. Buenos Aires: Verdaguer, 1957, [Barcelona: Lletra Viva. Llibres, 1982].

Tasis, R.: «Unes quantes dones, per Odó Hurtado», Mexico, Pont Blau, 39, gener (1956): 30-32.

Traverso, E.: Le passé, modes d'emploi. Histoire, mémoire, politique. Paris: La Fabrique 2005; Catalan translation used Els usos del passat. Història, memòria, política. Universitat de València: 2006. 